\title{
Inkubator Wirausaha Baru Agribisnis Peternakan dan Perikanan di Universitas Muhammadiyah Malang
}

\author{
Dr.Ir.Adi Sutanto, MM 1) \\ Prof. Dr. Ir. Wahyu Widodo, MS 2) \\ Ir.Ahmad Yani, M.P. 3) \\ Ir Suyatno M.Si 4)
}

\section{Ringkasan}

Inkubator Wirausaha Baru Agribisnis Peternakan dan Perikanan UMM telah melaksanakan kegiatan tahun II, beberapa kemajuan telah dicapai berkat dukungan dari para alumni yang telah mandiri dalam usaha serta mitra pengusaha.

Tujuan utama dibentuknya Inkubator Wirausaha Baru Agribisnis Peternakan dan Perikanan UMM telah mampu mendorong berkembangnya minat dari mahasiswa peternakan dan perikanan serta alumni baru lulus untuk belajar berwirausaha hingga merintis usaha. Hal ini ditunjukkan oleh makin meningkatnya calon peserta inwub dari tahun I sebanyak 5 kelompok usaha menjadi 11 calon peserta inwub pada tahun II dan didanai sebanyak 5 kelompok usaha.

Pelaksanaan inwub tahun II dimulai pada bulan April 2010 dan berakhir bulan Oktober 2010, dengan usaha yang telah diperluas baik bidang peternakan maupun perikanan. Dari 5 kelompok usaha yang ada, 3 kelompok usaha akan melanjutkan kegiatan usahanya dan tetap mendapatkan pendampingan dari inwub UMM baik terkait dengan bimbingan teknis maupun peningkatan sumber daya manusia kelompok usaha serta penyempurnaan dan penguatan kelembagaan kelompok usaha.

Rekomendasi keberlanjutan program kegiatan Inwub tahun III sebagai berikut :

1. Meningkatkan SDM kelompok-kelompok usaha wirausaha baru melalui kegiatan pelatihan dan pendampingan secara berkelanjutan.

2. Calon Wirausaha baru tidak hanya pada mahasiswa tingkat akhir dan alumni baru lulus, tetapi diberi kesempatan yang sama kepada mahasiswa - mahasiswa semester III s/d V, guna memberikan pengalaman usaha secara dini.

3. Inwub memperluas bidang usaha guna memberikan kesempatan kepada semua mahasiswa UMM yang memiliki minat yang baru untuk merintis usaha.

4. Mengoptimalkan fungsi alat-alat produksi secara efisensi dan perluasan jaringan usaha guna mendorong usaha yang produktif .

5. Mengembangkan kemampuan kelompok-kelompok usaha bergerak di bidang produk olahan guna meningkatkan nilai tambah produk.

1) 2) 3) 4) Staf Pengajar Fakultas Pertanian dan Peternakan UMM 
Jurnal Dedikasi Volume 7, Mei 2010

\section{A. Pendahuluan}

\section{Analisis Situasi}

Inkubator Wirausaha Baru di UMM

yang menggunakan konsep agribisnis harus memperhatikan dua hal penting. Pertama, berupaya memperkuat subsistem dalam satu sistem yang terintegrasi secara vertikal dalam satu kesatuan manajemen. Kedua, menciptakan usaha kecil yang efisien pada setiap subsistem. Jika hal ini dapat tercapai maka produk yang dihasilkan dari Inkubator Wirausaha Baru Agribisnis peternakan dan perikanan, berupa produk peternakan maupun perikanan berikut hasil olahannya akan mempunyai daya saing tinggi.

Permasalahannya tidak hanya sekedar bagaimana meningkatkan efisiensi usaha dalam agribisnis peternakan dan perikanan, tetapi keberhasilan Inkubator Wirausaha Baru Agribisnis Peternakan dan perikanan UMM tersebut akan sangat ditentukan oleh keharmonisan kerjasama tim (team-work) sumberdaya manusia yang berada pada keseluruhan subsistem agribisnis dari hulu sampai hilir, hal ini tentu saja harus melibatkan dan memadukan pelaku usaha baik dari masyarakat sekitar Malang, alumni yang sudah berhasil sebagai pengusaha dan alumni yang memulai usaha baru.

Sistem Inkubator Wirausaha Baru Agribisnis Peternakan dan perikanan UMM tidak akan dapat berkembang tanpa dukungan usaha usaha agribisnis para alumni yang sudah ada. Para alumni yang bekerjasama dengan fakultas peternakan dan perikanan UMM merancang, merekayasa dan melakukan proses agribisnis mulai dari proses produksi sampai ke proses pemasaran. Oleh karena itu tujuan dibentuknya Inkubator Wirausaha Baru
Agribisnis Peternakan dan perikanan UMM harus mampu mendorong berkembangnya wirausaha baru para alumni di bidang agribisnis peternakan dan perikanan .

Pembentukan Inkubator

Wirausaha baru agribisnis peternakan dan perikanan diterjemahkan sebagai upaya untuk peningkatan kuantitas, kualitas manajemen dan kemampuan untuk melakukan usaha secara mandiri maupun kemitraan dengan memanfaatkan peluang pasar. Potensi daerah Malang Raya sangatlah mendukung untuk berkembangnya usaha agribisnis peternakan dan perikanan, hal ini di karenakan Wilayah Malang Raya telah banyak usaha-usaha yang

sinergis dalam agribisnis adalah menyediakan tempat untuk melakukan percobaan dan praktikum mahasiswa. Namun semakin tingginya tuntutan kebutuhan Eksperimental farm juga mempunyai unit produksi yang bersifat profit oriented. Unit ini melakukan usaha, yaitu : Pabrik pakan unggas, Rumah Potong Ayam dan Budidaya ikan hias, budiaya udang windu, ayam potong , penggemukan sapi, ternak kambing dan domba.

Dengan dukungan fasilitas, sarana dan prasarana yang tersedia tersebut maka sangatlah memadai jika Eksperimental farm fakultas Peternakan perikanan sebagai wadah penggodokan terbentuknya wirausaha baru agribisnis peternakan dan perikanan, hal ini karena memenuhi sejumlah syarat sebagai tempat agribisnis peternakan dan perikanan, mulai dari ketersediaan bahan baku pakan, tersedianya pabrik pakan mini, beroperasinya Rumah Potong Ayam (RPA) meski dalam skala kecil, 
Adi Sutanto dkk. Inkubator Wirausaha Baru Agribisnis.

kolam outdoor dan indoor serta keberadaan fasilitas dan infrastruktur lainnya yang dapat digunakan untuk operasional usaha nantinya.

Berdirinya Inkubator wirausaha baru agribisnis peternakan dan perikanan juga berimbas pada peningkatan kesejahteraan melalui pencipataan lapangan kerja para alumni dan pengembangan Fakultas Peternakan Perikanan UMM menuju Fakultas yang mandiri.

\section{Tujuan Khusus dan Target Luaran}

\section{Kegiatan}

\subsection{Tujuan Khusus}

Tujuan khusus yang ingin dicapai dalam Inkubator Wirausaha Baru Agribisnis Peternakan dan perikanan di Universitas Muhammadiyah Malang :

1. Menciptakan Usaha Kecil Menengah di bidang agrisbisnis peternakan dan perikanan yang mandiri khususnya bagi para Mahasiswa dan lulusan baru sarjana peternakan.

2. Menciptakan lapangan kerja baru bagi masyarakat khususnya dibidang agribisnis peternakan dan perikanan.

3. Mengembangkan dan meningkatkan sinergitas usaha para alumni yang berwirausaha agribisnis peternakan dan perikanan diluar kampus dengan usaha agribisnis peternakan dan perikanan didalam kampus

4. Mengembangan jaringan kerja antara para alumni dengan pengusaha agribisnis peternakan dan perikanan.
5. Meningkatkan kerjasama dengan stakeholders (dinas, industri pakan, breeding farm, industri pengolahan hasil ternak/ikan, usaha peternakan/perikanan, dan lainlain).

\subsection{Target Luaran Kegiatan}

Target luaran yang ingin dicapai dalam Inkubator Wirausaha Agribisnis Peternakan dan perikanan ini adalah :

1. Terciptanya Usaha Kecil Menengah di bidang agribisnis peternakan dan perikanan yang mandiri khususnya bagi Mahasiswa dan para lulusan baru.

2. Terciptanya lapangan kerja baru bagi masyarakat khususnya dibidang agribisnis peternakan dan perikanan

3. Terbentuknya jalinan kerjasama usaha para alumni yang berwirausaha agribisnis peternakan dan perikanan diluar kampus dengan para lulusan baru yang berusaha dibidang agribisnis peternakan dan perikanan didalam kampus.

4. Terbentuknya jaringan kerja antara para alumni dengan pengusaha agribisnis peternakan dan perikanan.

5. Terbentuknya kerjasama dengan stakeholders (dinas, industri pakan, breeding farm, industri pengolahan hasil ternak/ikan, usaha peternakan/perikanan, dan lain-lain). 
Jurnal Dedikasi Volume 7, Mei 2010

\section{B. Metode Pelaksanaan Inwub}

Metode kegiatan IbK melalui agribisnis peternakan dan perikanan di UMM diawali dengan sosialisasi program di lingkungan kampus. Sosialisasi dimaksudkan untuk memberikan informasi tentang program IbK yang akan dilaksanakan kepada semua pihak di lingkungan fakultas/jurusan terutama bagi calon tenant yang akan mengikuti program ini. Sedangkan sosialisasi ekternal dimaksudkan untuk memberikan informasi tentang program IbK kepada industri mitra yang akan ditempati magang maupun kerjasama bentuk lainnya, pelaksanaan kunjungan lapang, pemda dan dinas/instansi terkait lainnya sebagai mitra strategis dalam mensukseskan program IbK peternakan dan perikanan.

\section{Pola Rekrutmen}

Pola rekrutmen Program IbK agribisnis peternakan dan perikanan ini dilaksanaan berdasarkan pada ketentuan bahwa calon tenant lebih diutamakan yang memperoleh program PKMK dan PKM lainnya yang didanai DP2M Dikti dengan memenuhi persyaratan yang telah ditentukan oleh Tim Pelaksana. Adapun persyaratan tenant peserta IbK agribisnis peternakan dan perikananUMM adalah :

1. Mahasiswa terdaftar pada jenjang pendidikan S-1 terutama yang mendapat program PKMK dan PKM lainnya yang didanai Dikti.

2. Mahasiswa lebih diutamakan dari jurusan Produksi Ternak, jurusan budidaya perikanan, jurusan
Teknologi Pengolahan Hasil Pertanian dan jurusan Manajemen.

3. Mahasiswa telah menempuh 100 SKS pada saat pelaksanaan IbK dan tidak boleh mengambil matakuliah dan atau praktikum selama mengikuti program.

4. Diijinkan dan dikirim oleh fakultas/ jurusan masing-masing.

5. Mahasiswa mengisi formulir kesediaan mengikuti program IbK.

6. Bersedia mematuhi ketentuan yang ditetapkan oleh Tim Pelaksana.

Mahasiswa calon peserta program IbK yang telah memenuhi persyaratan mendaftarkan diri dengan prosedur

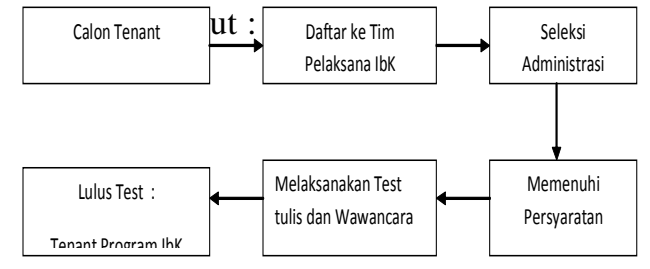

\section{Metode Pendekatan yang akan Diterapkan :}

Pelaksanaan program IbK melalui agribisnis peternakan dan perikanan ini akan dilaksanakan oleh Fakultas Peternakan UMM. Sedangkan pelaksanaan Magang dan kunjungan lapangnya akan dilaksanakan pada Industri Mitra agribisnis peternakan dan perikanan antara lain : Kelompok Peternak Agribisnis peternakan dan perikanan”ABI MANYU”, Gapoktan KADO Junrejo, UPT Agribisnis peternakan Singosari serta Balai Besar Inseminasi 
Adi Sutanto dkk. Inkubator Wirausaha Baru Agribisnis.

Buatan (BBIB) Singosari Kabupaten Malang, Balai benih ikan Punten. Mengingat prospek agribisnis peternakan dan perikanan yang semakin cerah dan sangat menjanjikan ditengah krisis global yang mendera dunia, maka program IbK agribisnis peternakan dan perikanan ini bertujuan mencetak calon wirausaha baru yang bergerak dibidang usaha agribisnis peternakan dan perikanan melalui perintisan dan pengembangan usaha, peningkatan populasi serta produksi dengan menjalin kerjasama dengan peternakan/perusahaan pembibitan agribisnis peternakan dan perikanan di Jawa Timur.

Berdasarkan beberapa kenyataan di lapangan maka metode pendekatan yang akan diterapkan adalah :

\section{Pelatihan Kewirausahaan}

Materi pelatihan kewirausahaan

diberikan kepada tenant sebelum dimagangkan kepada industri mitra, sebagai modal dasar tenant sebelum dimagangkan. Materi pelatihan dibagi menjadi 2 bagian yaitu : 1) Pemantapan kepribadian dan jiwa wirausaha yang terdiri dari : motivasi diri, negosiasi, kerjasama, kemandirian, leadership; 2) Materi dasar agribisnis peternakan dan perikanan yang terdiri dari :

perkandangan dan perlengkapan kandang, kolam dan persiapan kolam, pemilihan bibit/benih ternak/ikan, pakan dan transfer teknologi pakan, pengolahan limbah, penanganan penyakit, pembukuan sederhana dan pembuatan proposal kredit. Harapan dari program IbK agribisnis peternakan dan perikanan adalah terjadi transfer teknologi dalam usaha agribisnis peternakan dan perikanan dari Tim pengelola/pemateri ke mahasiswa/tenant. Melalui proses pelatihan dan pemagangan yang dilaksanakan secara rutin selama 2 bulan harapannya adalah terjadi alih teknologi secara sempurna dan dapat diterapkan oleh calon wirausaha baru secara berkelanjutan dan dapat menjadi sumber pendapatan dan menyerap tenaga kerja disekitar wilayah usahanya.

\section{Magang pada Industri Mitra}

Untuk lebih meningkatkan kemampuan, ketrampilan dan kepercayaan diri bagi para tenant IbK agribisnis peternakan dan perikanan maka akan diterjunkan ke industri mitra untuk melaksanakan magang dan kunjungan lapang ke Industri/Perusahaan agribisnis peternakan dan perikanan di Jawa Timur. Pelaksanaan magang lebih menekankan pada beberapa aspek mulai dari : 1) Pengembangan kepribadian dan jiwa entrepreneurship; 2) Aspek ketrampilan budidaya yang meliputi : Sistem perkandangan/kolam, pembibitan/ pembenihan, transfer teknologi pakan, perawatan ternak/ikan, 3.) Aspek kemampuan penanganan pasca panen yang meliputi : pengolahan aneka produk peternakan/perikanan, 3) Aspek kemampuan pengendalian dan penangan penyakit serta vaksinasi; 4) Pembuatan proposal kredit dan pembukuan sederhana; 5). Pengembangan kelembagaan diarahkan untuk pembinaan manajemen kelompok.

\section{Pelaksanaan Usaha}

Setelah peserta IbK telah mengikuti magang, maka Tim Pengelola IbK akan memberikan modal usaha bagi tenant baik secara individu maupun kelompok yang besarnya sekitar Rp. 10.000.000.- 
Jurnal Dedikasi Volume 7, Mei 2010

disamping itu tenant diharapkan akan mendapatkan tambahan modal dari tenant sendiri maupun dari instansi lain dalam bentuk kerjasama yang saling menguntungkan (kemitraan). Selama pelaksanaan usaha Tim Pengelola akan terus memberikan pendampingan usaha, bantuan teknologi maupun teknis yang diperlukan oleh tenant. Disamping itu membantu mencarikan kerjasama-kerjasama (kemitraan) yang saling menguntungkan sehingga tenant ini mampu menjadi wirausaha baru yang sukses dan berkembang.

\section{Pola Pembimbingan}

Pembimbingan selama program IbK agribisnis peternakan dan perikanan berlangsung, dilaksanakan oleh Tim Pelaksana bersama-sama dengan industri mitra selama tenant magang, sementara itu pmbimbingan sejak pelaksanaan program sampai tenant telah mampu beriwirausaha dilaksanakan oleh Tim Pelaksana sebagai unit yang bertanggungjawab dalam program IbK agribisnis peternakan dan perikanan di UMM. Kegiatan pembimbingan ini sekaligus sebagai usaha untuk melaksanakan pengawasan kepada tenant agar mengikuti dan melaksanakan kegiatan pelatihan ini dengan sungguh-sungguh dan memberikan dampak positif bagi tenant sebagai calon wirausaha baru. Dengan harapan sekitar 20 $\%$ (4 orang) tenant dari 20 orang, setelah selesai program IbK agribisnis peternakan dan perikanan ini diharapkan akan mengembangkan usaha yang telah diintis.

5. Pengawasan Terhadap Tenant

Pola pengawasan terhadap tenant diselenggarakan dengan menyiapkan daftar kegiatan harian yang dilakukan oleh tenant untuk diisi secara berkelanjutan baik selama mengikuti atau setelah program IbK selesai. Daftar isian kegiatan tersebut akan digunakan oleh Tim pelaksana untuk mengontrol kemajuan kegiatan tenant serta dilengkapi dengan dokumentasi kegiatan. Sementara itu selama kegiatan magang pengawasan terhadap tenant dilakukan secara bersama Tim Pelaksana dan Indusri Mitra.

6. Teknik Pembiayaan Tenant

Teknik pembiayaan usaha tenant direncanakan oleh Tim pengelola bersama tenant diupayakan dari 3 sumber yaitu : 1). Bantuan modal usaha dari program IbK, 2). Modal tenant sendiri dan 3). Kredit UMKM melalui mitra DPPM UMM yaitu Bank Jatim dengan bunga sangat rendah. Sedangkan selama program IbK berlangsung akan dibebankan kepada dana program DP2M Dikti dan dana dari UMM.

7. Pola Bantuan Teknologi Bantuan teknologi bagi tenant dalam bentuk :

a. Modul-modul teknologi tepat guna : pengolahan pakan, pengolahan produk ternak/ikan, pengolahan limbah menjadi biogas dan pupuk organik.

b. Bantuan alat-alat teknologi tepat guna (TTG) berupa : kincir air, mixer yang

dirancang bersama antara Tim Pelaksana, tenant dan Industri Mitra.

c. Bantuan teknis (Bintek) operasional alat-alat teknologi tepat guna

d. Bimbingan dan penyuluhan TTG. 
Adi Sutanto dkk. Inkubator Wirausaha Baru Agribisnis.

8. Metode Penyelesaian Masalah

Permasalahan-permasalahan yang

dihadapi oleh tenant selama program IbK

atau setelah memulai merintis usaha kambing akan dicarikan solusi atau diselesaikan oleh Tim Pelaksana dengan melibatkan industri mitra. Misalnya persoalan bahan baku pakan yang tidak kontinu, maka Tim Pelaksana akan berkoordinasi dengan Industri Mitra untuk mendapatkan bahan baku pakan.

\section{Kolaborasi dengan Lembaga Sejenis di Luar Kampus}

Program IbK melalui agribisnis peternakan dan perikanan yang dilaksanakan di UMM memiliki peluang untuk dikolaborasikan dengan lembaga sejenis di luar kampus terutama Kelompok agribisnis peternakan dan perikanan di Kecamatan Bumiaji dan Junrejo kota Batu, lembaga-lembaga pendidikan dan pelatihan atau balai latihan kerja baik negeri maupun swasta yang ada di Malang Raya. Kolaborasi yang telah dan akan dirintis melalui program IbK ini adalah :

1. Bank Jatim cabang Malang untuk penguatan permodalan yang sudah berjalan

kerjasamanya dengan DPPMUMM sejak tahun 2001.

2. Gabungan Kelompok Tani (Gapoktan) Kota Batu yang telah berjalan sejak tahun 2007

3. Dinas Pertanian Kota Batu untuk bantuan bibit dan Sapronak
4. Dinas Koperasi dan UKM serta Dinas Perdagangan dan Perindustrian.

5. PT. Ratu Ayam Indonesia

6. Lembaga Insan Indonesia Sejahtera (Bidang Agribisnis dan Agroindustri).

Sedangkan pola operasinya lebih ditekankan pada kemampuan manajemen dan keahlian Tim masing-masing lembaga sehingga terjadi saling melengkapi antara lembaga yang satu dengan lembaga yang lain dan pada akhirnya akan memberikan dampak yang sangat positif bagi tenant yang mengikuti program IbK untuk merintis usaha baru.

\section{Hasil Dan Pembahasan}

\section{Perencanaan dan Pelaksanaan}

Sosialisasi program IbK di UMM dimulai sejak awal bulan Mei sampai 15 Juni 2009. Program sosialisasi ini cukup panjang mengingat mahasiswa masih aktif dalam kegiatan kuliah dan praktikum, sehingga tidak memungkinkan untuk melaksanakan program IBK sedalam waktu yang cepat. Program sosialisasi dilakukan secara lisan dalam ruangan kuliah dan secara tertulis melalui pengumuman pada papan pengumuman di Jurusan Peternakan dan Jurusan Perikanan di UMM.

Pendaftaran IBK Agribisnis Peternakan dan Perikanan di UMM pada tanggal 15 s.d. 30 Juni 2009. Peserta yang mendaftar ada 11 kelompok usaha (Proposal). Dari 11 proposal yang diajukan kemudian diseleksi kelengkapannya oleh TIM Pelaksana IbK. Hal ini di maksudkan untuk melatih mereka agar punya 
Jurnal Dedikasi Volume 7, Mei 2010

pengalaman dalam penagjauan proposal usaha, pengalaman ini merupakan sentuhan softskill dalam berhubungan dengan pihak investor/perbankan

Dengan pengalaman pengajuan proposal usaha ini diharapkan mereka lebih percaya diri dalam memulai merintis dan menjalankan usahanya setelah mereka lulus sarjana nantinya.

Setelah mereka mengajukan permohonan pendaftaran melalui pengajuan proposal usaha untuk ikut dalam seleksi IbK Agribisnis Peternakan dan perikanan di Jurusan Peternakan dan Perikanan UMM maka para calon peserta IbK diwajibkan memaparkan rencana usahanya di depan TIM IbK UMM.

Pelaksanaan pemaparan rencana usaha dilakukan secara bergiliran oleh 11 kelompok usaha dengan membuat power point dan dipresentasikan. Masing masing kelompok diberi waktu \pm 45 menit.

Melalui diskusi dan tanya jawab, calon peserta IbK akan mendapatkan masukan / saran baik itu dalam hal proses produksi , pemasaran dll . Untuk itu mahasiswa disarankan untuk memperbaiki usulan usahanya walaupun nantinya tidak dibiayai namun akan dicarikan alternatif pembiayaan dari sumber yang lain.

Hasil akhir dari diskusi pemaparan usaha peserta IBK ini mereka akan mendapatkan rekomendasi dari TIM IBK . Rekomendasi berupa :

1. Rekomendasi Kelayakan Usaha (Usaha didanai atau tidak didanai)

2. Rekomendasi Pembiayaan Usaha ( Besar kecilnya Pembiayaan Usaha) Rekomendasi kelayakan usaha sebagai bukti bahwa usaha yang akan dikerjakan oleh calon peserta IbK telah melalui kajian yang mendalam dari TIM pelaksana IBK termasuk dalam besarnya pembiayaan. Bagi mereka yang tidak layak maka disarankan untuk memperbaiki usulan usahanya. Namun dari 11 proposal yang mendaftar, terdapat 5 proposal yang dinyatakan layak untuk dibiayai usahanya.

Setelah terseleksi 5 proposal dengan jumlah 11 orang selanjutnya dilaksanakan pelatihan usaha dan magang/ kunjungan ke mitra pengusaha agar calon peserta mendapatkan pengetahuan dan pengalaman sebagai modal dasar dalam melakukan usaha nantinya. Setelah usaha berjalan akan dilaksanakan monitoring dan evaluasi terhadap usaha yang dijalankan.

Bantuan pinjaman dana usaha diberikan kepada mereka yang dinyatakan layak usaha. Bantuan pinjaman usaha untuk peserta IBK berkisar 5 - 10 Juta tergantung besaran skala usaha. Bantuan pinjaman diatur oleh TIM IBK melalui suatu administrasi seperti layaknya masyarakat yang mengajukan pinjaman usaha di Bank, dengan tujuan untuk melatih mereka berani menanggung resiko keuangan apabila dalam menjalankan usaha mereka rugi, selain itu juga pemberian pinjaman modal usaha yang diberikan ke peserta IBK bertujuan melatih tanggungjawab ketua kelompok dan anggotanya kepada lembaga IBK.

Setelah peserta IBK mendapat bantuan pembiayan usaha, rata rata mereka mulai mengerjakan usahanya sekitar bulan Juli dan Agustus 2009. Adapun 6 proposal yang layak dibiayai yang kemudian untuk usaha mandiri perorangan dan jumlah anggotanya terlalu sedikit digabungkan menjadi hanya 5 kelompok usaha yaitu : 
Adi Sutanto dkk. Inkubator Wirausaha Baru Agribisnis.

\section{Wirausaha Mandiri (Retno Safitri S.Pt dan Izwar Anaz)}

Kelompok usaha ini dilakukan oleh

alumni UMM dan melibatkan 1 orang mahasiswa tugas akhir. Adapun usaha yang telah dirintis adalah usaha ayam petelur kampung yang memiliki potensi pasar yang sangat besar untuk wilayah Malang Raya. Usaha ini dilakukan di luar kampus ( Tenant Outwall), dan hanya berjarak 2 KM dari kampus sehingga TIM IBK dapat melaksanakan monitoring dan evaluasi sewaktu-waktu terhadap perkembangan usaha ini. Adapun tujuan dilibatkannya 1 orang mahasiswa tugas akhir untuk ikut berwirausaha di alumni adalah memberikan kesempatan kepada mahasiswa untuk belajar berusaha terlebih dahulu sebelum berwirausaha secara mandiri. Keunggulan usaha ayam kampung petelur adalah produksi telur cukup tinggi, pemasaran mudah, harga telur tinggi, kebutuhan pakan rendah dan setelah ayam diafkir, harga jual masih cukup tinggi.

Usaha budidaya ayam petelur kampung ini dilakukan di desa Sumber Sekar Kecamatan Dau Kabupaten Malang dengan ukuran kandang 5 X $6 \mathrm{~m}$ diisi untuk periode pertama 200 ekor. Ternak ayam kampung yang dipelihara adalah ayam arab dengan keunggulannya adalah produksi telur dapat mencapai 200 s.d. 250 butir per ekor per tahun.

Pemasaran telur ayam kampung sangat mudah dimana pembeli langsung datang ke peternak. Peternak tidak perlu menawarkan dengan cara diantar ke pasar melainkan cukup menunggu di kandang saja, sementara harga telur ayam ini dapat mencapai Rp. 1.500 per butir.

\section{Kelompok Usaha Ternak Kambing PE ( Riza Indriawan dan Sinar Bakti )}

Usaha kambing PE ini merupakan

kelompok usaha yang dilakukan oleh Mahasiswa tingkat akhir dengan jumlah mahasiswa yang terlibat 3 orang, melalui kerjasama kelompak mahasiswa ini sangat percaya diri dalam usaha, hal ini terlihat dari usaha mereka untuk pertamakali sudah membuat 1 unit kandang kambing PE dengan kapasitas 50 ekor dan telah terisi 20 ekor dengan luas areal usaha 250 meter persegi. Kandang berlokasi di desa Macanan Kecamatan Loceret Kabupaten Nganjuk. Adapun alasan mereka merintis usaha di Nganjuk adalah karena daerah Nganjuk, usaha peternakan kambing PE masih langka dibanding daerah Blitar, Tulungagung dan Malang, sehingga sangat berpeluang untuk dikembangkan melalui kerjasama dengan dinas Peternakan setempat.

Saat dilaksanakan monitoring oleh TIM IBK pada awal Oktober 2009, menunjukkan bahwa sistem pemeliharaan secara intensif dengan pola pemberian pakan hijauan dan konsentrat, perkawinan dilaksanakan secara alami dengan pejantan unggul, litter size rata-rata 2. Sedangkan produksi susu sementara masih digunakan untuk cempe yang dalam pengembangannya akan diarahkan untuk produksi susu kambing PE dengan harga jual dapat mencapai Rp. 15.000.-/liter. Saat ini dalam menyambut hari raya Idul Adha direncanakan akan dijual pejantan-pejantan yang tidak produktif dengan harapan dapat memperoleh tambahan penghasilan ketika harga jual tinggi. 
Jurnal Dedikasi Volume 7, Mei 2010

\section{U.D. COLEGA TIGRE}

Kelompok usaha ini adalah mahasiswa di jurusan perikanan tingkat akhir yang diketuai oleh : Wildan Zaki dengan anggota Benedito Manuel Alves dan Maria De Assuncao D.X. (Mahasiswa Tingkat Akhir). Adapun usahanya adalah pembesaran udang Vannamei yang berlokasi di desa Rambit Kecamatan Sedayu Kabupaten Gresik Jawa Timur.

Tambak yang disewa untuk usaha pembesaran udang Vannamei ini seluas 1500 meter persegi dengan ukuran $75 \mathrm{~m}$ x 20 meter. Tenaga yang dipekerjakan 1 orang sebagai pekerja kasar yang betugas untuk pembalikan tanah dan memberi pakan udang setiap hari. Pembesaran udang dilakukan dengan semi intensif. Pada awal penebaran (benur berumur ( 1 - 30 hari) diberi pakan berupa bentuk crumble, sedangkan udang pada umur 30 hari sampai panen diberi pakan pellet.

Setelah panen udang Vannamei ini dijual di lokasi sekitar Kecamatan Sedayu, Sekapuk, Paciran, Sembayat, Bungah dan Kecamatan Manyar. Potensi pemasaran udang Vannamei cukup bagus karena harga udang Vannamei relatif stabil sehingga dapat meningkatkan kehidupan para petani tambak.

\section{Kelompok Usaha Bulung Indah}

Kelompok usaha ini adalah mahasiswa di jurusan perikanan tingkat akhir yang diketuai oleh : Budi Cahyono dengan anggota Guilherme T. Gomes, Ikang Fauzi (Mahasiswa Tingkat Akhir). Usaha yang dilaksanakan adalah budidaya rumput laut kelas Euchema dengan sistem rakit yang berlokasi di dusun Jumiang, desa Tanjung,
Kecamatan Pademawu, Kabupaten Pamekasan propinsi Jawa Timur.

Usaha ini dilaksanakan pada 5 rakit dengan ukuran $14 \mathrm{~m} \mathrm{x} 4 \mathrm{~m}$ untuk 2 rakit dan ukuran 12 m x 10 m untuk 3 rakit, lama usaha budidaya rumput untuk satu periode panen 40 hari. Harga bibit rumput laut Rp. 1.500.-/kg sedangkan bila dijual saat panen dengan harga Rp. 1.400,-/kg. Usaha budidaya rumput laut ini cukup menjajnjikan baik dalam hal periode pemeliharaannya yang singkat maupun pemasaran. Pemasaran rumput sangat mudah karena setiap panen sudah dituggu oleh pembeli.

Salah satu faktor yang mempengaruhi produksi rumput laut adalah musim, dimana pada musim kemarau produksi rumput laut menurun sedangkan pada musim hujan produktifitasnya meningkat. Umumnya pada musim hujan 2 kali panen sudah dapat keuntungan sedangkan pada musim kemarau 2 kali panen belum tentu kembali modal.

\section{Usaha Budidaya Ikan Nila}

Kelompok usaha ini adalah mahasiswa di jurusan perikanan tingkat akhir yang dikelola oleh : M. Zainal Alim. Usaha ini berlokasi di desa Tebas Kecamatan Gondangwetan Kabupaten Pasuruan Jawa Timur.

Kolam yang dimiliki berjumlah 15 unit yang terdiri dari kolam induk 5 unit, kolam pembenihan 10 unit. Untuk mengelola usaha dipekerjakan 4 orang dengan tugas yang telah ditentukan oleh Pengelola. Adapun masa produksi per periode hanya 1 bulan. Usaha ini dapat berjalan dan berkembang dengan sistem kemitraan dengan beberapa pihak yaitu 
Adi Sutanto dkk. Inkubator Wirausaha Baru Agribisnis.

Pengusaha dan CP Prima. Peran terbesar yang dapat membangkitkan semangat dalam usaha ini adalah bantuan finasial dan bantuan teknis dari TIM IBK UMM yang telah mendorong kami untuk mulai merintis usaha agar setelah lulus nantinya dapat berwirausaha dan membuka lapangan kerja baru bagi masyarakat dan tidak mencari pekerjaan.

Pelaksanaan pelatihan kewirausahaan diselenggarakan di Kampus UMM dengan menanfaatkan fasilitas yang ada di lingkungan kampus UMM sedangkan untuk magang usaha disesuaikan dengan jenis usaha yang akan dirintis oleh masingmasing tenant yang telah dinyatakan diterima atau didanai sesuai dengan proposal yang telah diajukan.

Setiap kelompok usaha dibimbing selama pelaksanan program IbK oleh 2 dosen. Konsultasi dengan pembimbing dapat dilakukan oleh peserta IbK sewaktu waktu. Peserta IbK bisa konsultasi dan Pembimbing diwajibkan untuk memonitor usaha peserta IbK yang dibimbingnya

Teknik pembiayaan usaha tenant direncanakan oleh Tim pengelola bersama tenant diupayakan dari 3 sumber yaitu : 1). Bantuan modal usaha dari program IbK, 2). Modal tenant sendiri dan 3). Kredit UMKM melalui mitra DPPM UMM yaitu Bank Jatim dengan bunga sangat rendah. Sedangkan selama program IbK berlangsung akan dibebankan kepada dana program DP2M Dikti dan dana dari UMM.

7. Pola Bantuan Teknologi

Bantuan teknologi bagi tenant dalam bentuk :

a. Modul-modul teknologi tepat guna : pengolahan pakan, pengolahan produk ternak/ikan, pengolahan limbah menjadi biogas dan pupuk organik.

b. Bantuan alat-alat teknologi tepat guna (TTG) berupa : kincir air, mixer yang dirancang bersama antara Tim Pelaksana, tenant dan Industri Mitra.

c. Bantuan teknis (Bintek) operasional alatalat teknologi tepat guna

d. Bimbingan dan penyuluhan TTG.

\section{Wirausaha Baru Mandiri Yang Dihasilkan Per Tahun}

INWUB Perunggasan di Jurusan Peternakan Tahun I di buka pada awal Bulan April 2008 dan berakhir bulan Oktober 2008 ini diikuti oleh 7 Peserta yang terbagi dalam 3 kelompok usaha yaitu :

a. Kelompok Usaha Taruna Jaya 81 FARM

Kelompok usaha ini adalah mahasiswa di jurusan peternakan tingkat akhir yang diketuai oleh : Fredi Antok dengan 2 anggota yaitu Kradiansyah dan Hana Ibnu M (Mahasiswa Tingkat Akhir) dengan usaha yang dilaksanakan yaitu budidaya ayam potong.

b. Kelompok Usaha Putra Putri Mandiri

Kelompok usaha ini adalah mahasiswa di jurusan peternakan tingkat akhir yang diketuai oleh : Susanto dengan 2 anggota anggota yaitu Didit Eko P dan Ahmad Balafif (Mahasiswa Tingkat Akhir). Usaha yang dilaksanakan adalah budidaya ayam potong dengan bermitra dengan PT. Comfeed Indonesia. 
Jurnal Dedikasi Volume 7, Mei 2010

c. Kelompok Usaha peternakan ayam Mandiri

Kelompok usaha ini adalah Alumni di Jurusan peternakan yang diketuai oleh : Khoiryah, Spt juga usaha ayam potong dengan pencampuran pakan sendiri sehingga terdapat efisiensi dalam biaya pakan.

Untuk tahap pertama ini mahasiswa yang bisa mendaftar sebagai peserta INWUB perunggasan adalah Mahasiswa tingkat akhir, hal ini di maksudkan untuk melatih mereka agar punya pengalaman usaha, pengalaman usaha ini merupakan modal mereka untuk memupuk kepercayaan mahasiswa untuk berani berwirausaha diluar kampus apabila mereka lulus, dikatakan sebagai modal karena, selama berwirausaha ada sentuhan Softskill yang diperoleh mahasiswa terutama dalam berani menanggung resiko keuangan, resiko waktu dan melatih kerjasama ( team work ) antar mahasiswa.

Secara umum pengalaman usaha para peserta INWUB masih rendah hampir $80 \%$ dari peserta inwub semuanya belum pernah punya pengalaman usaha. Hal ini sangat mempengaruhi keberanian mereka dalam usaha ini terbukti dengan jumlah skala usaha yang mereka kelola rata rata hanya 200 sampai 300 ekor. Namun untuk alumni yang sudah punya pengalaman usaha mereka lebih berani ini bisa dilihat dari jumlah populasi sekitar 700 ekor.

Pelaksanaan IbK (INWUB Tahun II) telah dikembangkan tidak hanya pada agribisnis perunggasan tetapi telah diperluas menjadi agribisnis peternakan dan perikanan. Pendaftaran IBK Agribisnis
Peternakan dan Perikanan di UMM pada tanggal 15 s.d. 30 Juni 2009. Peserta yang mendaftar ada 11 kelompok usaha (Proposal) yang diajukan secara berkelompok maupun perorangan. Setelah diseleksi yang dinyatakan dibiayai untuk melaksanakan program IbK sebanyak 5 Kelompok usaha yang terdiri dari 11 orang peserta.

Tabel 1. Wirausaha Baru Yang Dihasilkan Per Tahun

\begin{tabular}{|c|c|c|c|c|c|c|}
\hline \multirow[b]{2}{*}{$\mathrm{N}_{0}$} & \multirow[b]{2}{*}{ Tahun } & \multicolumn{2}{|c|}{ Calon } & \multicolumn{2}{|c|}{ Dibiayai } & \multirow{2}{*}{$\begin{array}{c}\text { Menjadi } \\
\text { Wirausaha Baru }\end{array}$} \\
\hline & & Peserta & Kelompok & Peserta & Kelompok & \\
\hline 1 & 2008 & 7 & 3 & 7 & 3 & 4 \\
\hline 2 & 2009 & 20 & 11 & 11 & 5 & 7 \\
\hline & Jumlah & 27 & 14 & 18 & 8 & 11 \\
\hline
\end{tabular}

$\checkmark$

mahasiswa sebelum dan setelah menjadi tenat untuk program tahun 2009 disajikan

pada Tabel 2 berikut ini : 
Adi Sutanto dkk. Inkubator Wirausaha Baru Agribisnis.

Tabel 2. Kondisi Usaha Mahasiswa Sebelum dan Setelah Menjadi Tenant

\begin{tabular}{|c|c|c|c|}
\hline No & Jenis Usaha & Kondisi Sebelum & $\begin{array}{c}\text { Kondisi Setelah Menjadi } \\
\text { Tenant }\end{array}$ \\
\hline 1 & $\begin{array}{l}\text { Ayam Kampung } \\
\text { Petelur }\end{array}$ & $\begin{array}{l}\text { - Usaha ayam kampung } \\
\text { secara semi intensif } \\
\text { - Populasi } 25 \text { ekor } \\
\text { - Pakan seadanya }\end{array}$ & $\begin{array}{l}\text { - Usaha ayam kampung } \\
\text { secara intensif } \\
\text { - Populasi } 200 \text { ekor } \\
\text { - Pakan campur sendiri dgn } \\
\text { sistem komputer }\end{array}$ \\
\hline 2 & Kambing PE & $\begin{array}{l}\text { - Usaha kambing secara } \\
\text { semi intensif } \\
\text { - Populasi } 4 \text { ekor } \\
\text { - Pakan seadanya }\end{array}$ & $\begin{array}{l}\text { - Usaha ayam kambing } \\
\text { secara intensif } \\
\text { - Populasi } 15 \text { ekor } \\
\text { - Pakan komplit Feed }\end{array}$ \\
\hline 3 & Udang Vannamei & $\begin{array}{l}\text { - Bekerja sebagai tenaga } \\
\text { lepas usaha udang }\end{array}$ & $\begin{array}{l}\text { - Budidaya udang vannamai } \\
\text { intensif } \\
\text { - Luas Tambak } 1500 \text { meter } \\
\text { persegi } \\
\text { - dikelola berkelompok }\end{array}$ \\
\hline 4 & Rumput Laut & $\begin{array}{l}\text { - Belum memiliki usaha } \\
\text { - Bekerja membantu orang } \\
\text { tua }\end{array}$ & $\begin{array}{l}\text { - Budidaya rumput laut } \\
\text { - Memiliki } 4 \text { rakit ukuran } \\
10 \mathrm{~m} \mathrm{x} 6 \mathrm{~m} \\
\text { - Produksi } 400 \mathrm{~kg} \text { panen }\end{array}$ \\
\hline 5 & Ikan Nila & $\begin{array}{l}\text { - Magang pada pembibitan } \\
\text { nila pak Hartoyo }\end{array}$ & $\begin{array}{l}\text { - Produksi nila dan benih } \\
\text { Nila } \\
\text { - Sewa } 15 \text { kolam } \\
\text { - Bibit diekspor Singapura. }\end{array}$ \\
\hline
\end{tabular}

\section{Rencana Bisnis Yang Drealisasikan}

Berdasarkan rencana kegiatan INWUB tahun I menunjukkan bahwa rencana bisnis yang telah dusun belum mencapai hasil yang diharapkan antara lain keuntungan yang diharapkan oleh masingmasing kelompok belum menggembirakan karena berbagai hal antara lain : 1 . Harga pakan ayam yang tinggi adalah pakan jadi
3. Harga jual ayam saat panen mengalami penurunan tajam.

4. Pengalaman berusaha tenant masih kurang.

5. Hanya melaksanakan usaha sejenis (ayam potong)

Belajar dari pengalaman INWUB tahun I, maka pada pelaksanaan INWUB 
Jurnal Dedikasi Volume 7, Mei 2010

tahun II telah dilakukan program pengembangan antara lain :

1. Bidang usaha diperluas yaitu peternakan dan perikanan

2. Seleksi peserta dilaksanakan

dengan mempertimbangkan motivasi dan pengalaman calon peserta.

3. Program kegiatan meliputi : pelatihan usaha, magang pada mitra dan perintisan usaha.

4. Memperluas jaringan pemasaran dan jaringan kemitraan

5. Monitoring dan evalasi selama kegiatan

ditingkatkan.

Setelah berlangsung kegiatan pada tahun II menunjukkan bahwa jumlah peserta/kelompok usaha yang berminat semakin tinggi dan rencana bisnis yang direalisasikan tercapai yaitu : Meningkatkan jumlah dan kualitas peserta program dari tahun I dan variasi usaha yang dilaksanakan.

\section{Kesimpulan Dan Saran \\ 1. Kesimpulan}

Merujuk dari hasil pelaksanaan dan pembahasan program INWUB diatas dapat disimpulkan bahwa perlu adanya penyempurnaan pada kemitraan dan pembinaan agar lebih terarah dan berkembang, perluasan bidang usaha yang lebih kompetitif, perluasan kesempatan mengikuti program bagi mahasiswa sejak dini agar lebih matang dalam berwirausaha. Disamping itu perlu pengembangan usaha INWUB dengan memanfaatkan seluruh potensi yang ada di UMM melalui program kewirausahaan berbasis pada pemanfaatan fakultas laboratorium dan SDM yang ada.

\section{Saran}

Diperlukan adanya tindak lanjut yang terpola dengan baik melalui kegiatan : membangun jejaring kerjasama dengan perusahaan atau alumni yang telah sukses terutama dibidang peternakan dan perikanan untuk melakukan kemitraan usaha dengan peserta INWUB, melatih suatu ketrampilan peserta sesuai dengan usaha yang ditekuninya, bermitra dengan baik guna mendapatkan modal usaha dan memanfaatkan teknologi tepat guna yang berwawasan lingkungan.

\section{DAFTAR PUSTAKA}

Amin A, 1997. Pola Kemitraan Sebagai Upaya Memantapkan Agribinis dan Pemberdayaan Ekonomi Rakyat. Makalah Seminar Fakultas Pertanian UMM. 
Adi Sutanto dkk. Inkubator Wirausaha Baru Agribisnis.

\section{Lampiran}
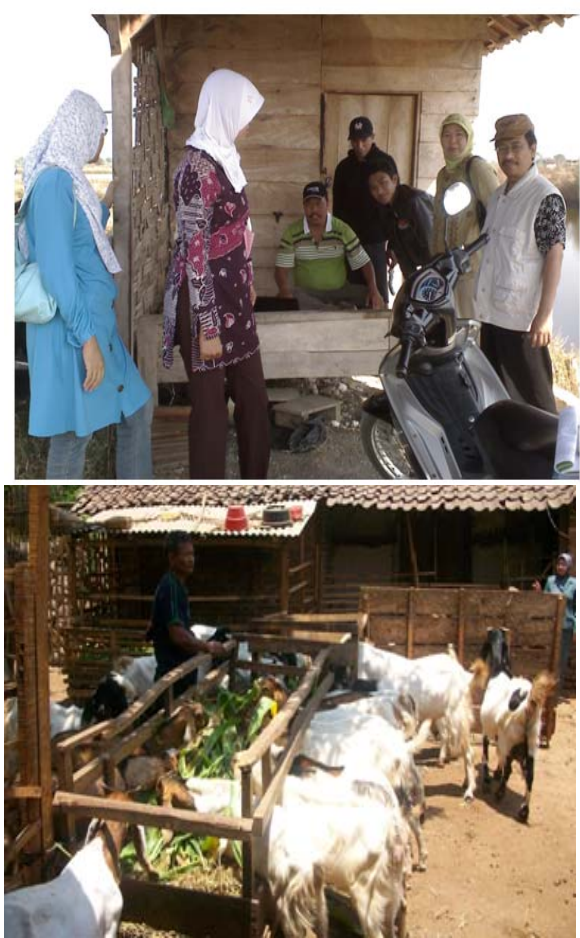

Usaha Ternak Kambing - Kabupaten Nganjuk

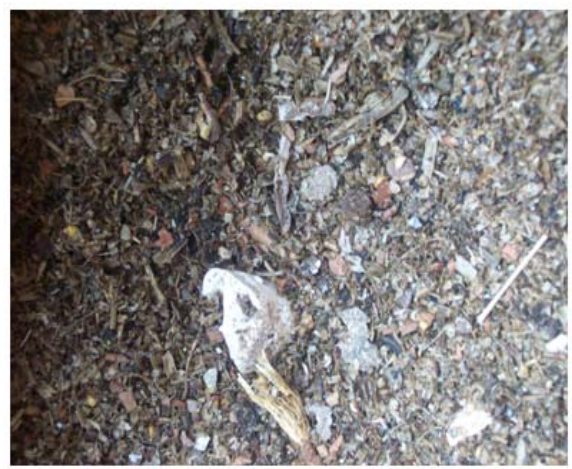

Usaha Budidaya Rumput Laut

Pamekasan Madura
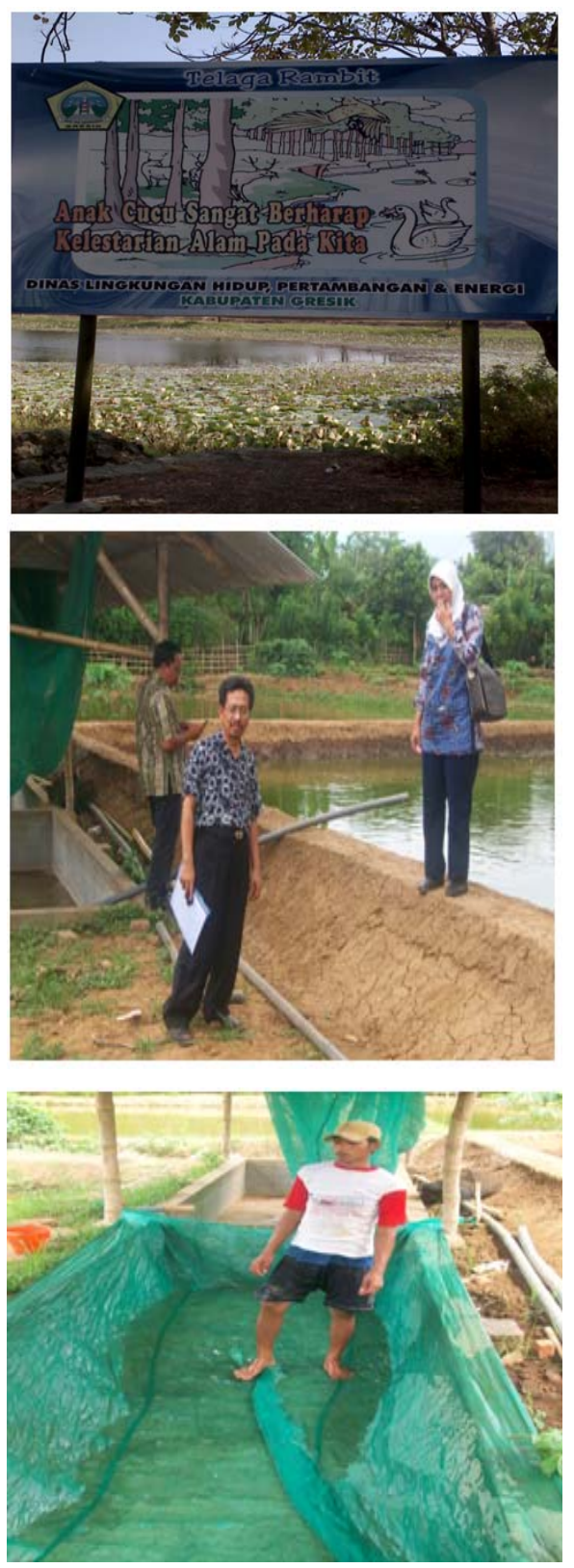

Usaha Budidaya Udang Vannamei 
Jurnal Dedikasi Volume 7, Mei 2010 